\title{
Mitogen-induced stimulation and suppression of erythroid burst promoting activity production by human mononuclear cells
}

Kenneth S. Zuckerman And MAr y Ha AK Division of Hematology and Oncology. Department of Internal Medicine, Simpson Memorial Research Institute, University of Michigan, Ann Arbor, Michigan, U.S.A.

Received 1 November 1982; accepted for publication 17 February 1983

SUMMARY. Exposure of human peripheral blood mononuclear cells or highly enriched monocytes to various plant lectins substantially alters their production of erythroid burst promoting activity (BPA). Neither unstimulated, nor mitogen stimulated, enriched T lymphocytes produced demonstrable BPA. Each of the lectins tested resulted in a different pattern of alteration of BPA production by mononuclear cells. Increasing concentrations of phytohaemagglutinin (PHA) caused a progressive increase in BPA production up to a plateau level at concentrations above $0 \cdot 25-0.5$ $\mu \mathrm{l} / \mathrm{ml}$. Concanavalin A (Con A) at concentrations of $0 \cdot 05-0 \cdot 1 \mu \mathrm{g} / \mathrm{ml}$ stimulated BPA production, but Con A concentrations $>1 \mu \mathrm{g} / \mathrm{ml}$ never augmented BPA production by mononuclear cells. Pokeweed mitogen inhibited BPA production by mononuclear cells in a concentration-dependent manner. Since PHA and Con A can bind to and stimulate both monocytes/macrophages and T lymphocytes, some production of BPA by stimulated $\mathrm{T}$ cells in the presence of monocytes cannot be ruled out. Earlier studies demonstrated that $\mathrm{T}$ cells augment monocyte production of BPA. Thus, monocyte-T cell interactions, as well as activation of monocytes and perhaps lymphocytes, play an important role in regulation of BPA production in vitro.

Early erythroid progenitor cells, BFU-E, are not dependent on erythropoietin for their maintenance or proliferation in vivo (Hara \& Ogawa, 1977; Iscove, 1977) or in vitro (Iscove, 1978; Tsang \& Aye, 1979). Another material, most frequently termed burst promoting activity (BPA), has been proposed as a major regulator of BFU-E. Cellular sources of human BPA include whole bone marrow (Porter \& Ogawa, 1982), peripheral blood mononuclear cells (Zuckerman, 1980; Nathan et al, 1978; Aye, 1977; Eaves \& Eaves, 1978), monocytes (Zuckerman, 1980, 1981; Reid et al, 1981), macrophages (Gordon et al, 1980), T lymphocytes (Nathan et al, 1978; Mangan \& Desforges, 1980; Mangan et al, 1982; Reid et al,

Correspondence: Dr Kenneth S. Zuckerman, Simpson Memorial Institute, 102 Observatory, Ann Arbor, MI 48109, U.S.A. 
1981). non-monocyte. non-T cell mononuclear cells (Meytes et al. 1979), and human $T$ lymphoblastic and monocytic cell lines (Golde et al, 1980: Hamburger, 1980; Abboud et al, 1980: Ascensao et al. 1981). BPA also has been found in human serum (Nissen et al, 1979) and urine (Dukes et al, 1978). Previous reports from this laboratory have demonstrated that monocytes play a critical role in the stimulation of human BFU-E growth in vitro and that $\mathrm{T}$ lymphocytes augment the BFU-E stimulatory effects of monocytes (Zuckerman, 1981). We also have shown that media conditioned by unstimulated mononuclear cells, monocytes. and possibly $\mathrm{T}$ lymphocytes contain BPA (Zuckerman. 1980). In the present study we have confirmed the production of BPA by human mononuclear cells and by highly purified monocytes. In addition. we have demonstrated that BPA production by these cells is modified substantially by various plant lectins.

\section{MATERIALS AND METHODS}

Human subjects. All studies were approved by the institutional committee for the protection of human subjects at the University of Michigan. After informed consent, peripheral blood was obtained by venipuncture from normal human volunteers ranging in age from 21 to 54 years. Blood was anticoagulated with preservative-free heparin, 10 units per $\mathrm{ml}$ of blood.

Isolation of cell populations. Mononuclear cells were isolated by ficoll-hypaque density centrifugation (Bøyum, 1968). Cell differential counts were done using Wright-Giemsa and alpha-naphthyl butyrate esterase staining (Tucker et al. 1977), and T lymphocytes were identified by rosetting with sialidase-treated sheep erythrocytes (Mendes et al, 1973). Mononuclear cells contained $15-28 \%$ monocytes and $72-85 \%$ lymphoid cells, with $58-70 \%$ T lymphocytes.

Adherent cells, which were always $\geqslant 96 \%$ monocytes, were obtained by the previously described modifications (Zuckerman. 1981) of the method of Shaw et al (1978). These monocyte-enriched populations are designated in the remainder of this paper as 'monocytes'.

Nonadherent cells, obtained after two consecutive $90 \mathrm{~min}$ adherence procedures in tissue culture dishes (Zuckerman. 1981). were always $\geqslant 97 \%$ lymphoid cells. In the remainder of this paper these cell populations are designated as non-adherent mononuclear cells or monocyte depleted mononuclear cells.

T lymphocytes were enriched ( $\geqslant 96 \% \mathrm{~T}$ cells and $\leqslant 1 \cdot 5 \%$ monocytes) from suspensions of non-adherent mononuclear cells by the sheep cell rosette and density centrifugation technique (Zuckerman, 1980, 1981: Mendes et al, 1973). These cell populations are designated ' $T$ lymphocytes' or ' $T$ cells' in this paper. $T$ lymphocyte depleted mononuclear cells were recovered from the interface above the ficoll-hypaque. These suspensions contained $<5 \%$ T lymphocytes.

All cell populations used contained $>95 \%$ viable cells as determined by trypan blue dye exclusion.

Human peripheral blood BFU-E assay. The plasma clot culture technique of Tepperman et al (1974) was altered as described previously (Zuckerman. 1981). Briefly, Iscove's modified Dulbecco's medium (IMDM) (Grand Island Biologicals Co., Grand Island, N.Y.) was used as 
the medium in which cells were cultured. Human AB serum ( $10 \%$ final concentration) was used in place of $30 \%$ fetal bovine serum. Human urinary erythropoietin (generously provided by the National Heart, Lung and Blood Institute) was used at a final concentration of 1. unit/ml $(0.5$ unit per $0.5 \mathrm{ml}$ culture dish). Unfractionated mononuclear cells, monocyte depleted mononuclear cells, or T lymphocyte depleted mononuclear cells were cultured at a cell density of only $10^{5}$ per culture in order to minimize even further the low numbers of contaminating cells (monocytes or $\mathrm{T}$ cells) that were to have been removed from cell populations being evaluated for their BFU-E content.

Preparation of conditioned media. Unfractionated peripheral blood mononuclear cells, 'monocytes' or ' $\mathrm{T}$ cells' were suspended in IMDM containing 10\% human $\mathrm{AB}$ serum, penicillin 50 units $/ \mathrm{ml}$ and streptomycin $50 \mu \mathrm{g} / \mathrm{ml}$. Mononuclear cells or 'T lymphocytes' were incubated at a concentration of $10^{6}$ cells $/ \mathrm{ml}$. 'Monocytes' were incubated at a concentration of $10^{5}$ cells $/ \mathrm{ml}$ because of our previous finding that higher monocyte concentrations resulted in decreased BPA (Zuckerman, 1980). The following mitogens were added to selected mononuclear cell suspensions to evaluate their effects on BPA production and release into conditioned medium: Phytohaemagglutinin (PHA) (Difco, Detroit) $0 \cdot 1-1 \cdot 0$ $\mu \mathrm{l} / \mathrm{ml}$ (optimum concentration for stimulation of lymphocyte thymidine incorporation $0 \cdot 25$ $\mu \mathrm{l} / \mathrm{ml}$ ); Pokeweed mitogen (PWM) (Sigma Chemical Co., St Louis) 0 $25-10 \mu \mathrm{l} / \mathrm{ml}$ (optimum concentration for stimulation of lymphocyte thymidine incorporation $2.5 \mu \mathrm{l} / \mathrm{ml}$ ); and Concanavalin A (Con A) (Sigma Chemical Co., St Louis) $0 \cdot 01-10 \mu \mathrm{g} / \mathrm{ml}$. Cells with or without mitogens were cultured in $35 \mathrm{~mm}$ Lux or Falcon tissue culture dishes for $4 \mathrm{~d}$ at $37^{\circ} \mathrm{C}$ in an atmosphere of $5 \% \mathrm{CO}_{2}$ in air and $95-100 \%$ humidity. In control cultures varying concentrations of mitogens were added to IMDM with $10 \% \mathrm{AB}$ serum but no cells. At the end of the $4 \mathrm{~d}$ culture period the medium was aspirated from the culture plates, centrifuged at 400 $g$ for $12 \mathrm{~min}$, passed through a $0.22 \mu \mathrm{m}$ filter, and frozen at $-20^{\circ} \mathrm{C}$ until being assayed for BPA.

Assay for burst promoting activity in conditioned media. Previous studies from this laboratory demonstrated that BFU-E growth from human peripheral blood mononuclear cells was decreased by $89 \%$ when monocytes were depleted, and that BFU-E were restored to normal by adding monocytes back to the cultures (Zuckerman, 1980, 1981). In contrast, there was no decrease in BFU-E growth when $\mathrm{T}$ lymphocytes were removed from the mononuclear cells (Zuckerman, 1980, 1981). Therefore, medium conditioned by mononuclear cells, 'monocytes' or ' $\mathrm{T}$ lymphocytes' was assayed for BPA in cultures of $10^{5}$ monocyte depleted mononuclear cells. ' $\mathrm{T}$ lymphocyte' conditioned medium also was assayed against $\mathrm{T}$ cell depleted mononuclear cells. BPA was quantitated by comparing the number of BFU-E in cultures containing conditioned medium to BFU-E numbers in control cultures without conditioned medium.

Although production and release of BPA may be two independent phenomena, for the sake of clarity in the remainder of this paper we use BPA production to mean production and/or release. 


\section{RESULTS}

Production of erythroid burst promoting activity by human peripheral blood mononuclear cells

BPA content of media conditioned by the various cell populations cultured in the presence or absence of mitogens is expressed in Fig 1 as number of BFU-E in cultures containing $10^{5}$ non-adherent cells and $10 \%$ conditioned medium. Cultures of $10^{5}$ mononuclear cells contained $33 \cdot 7 \pm 3 \cdot 3$ BFU-E (data not shown in Fig 1 ), and there were $3 \cdot 8 \pm 0 \cdot 4$ BFU-E per $10^{\overline{3}}$ monocyte depleted mononuclear cells in cultures lacking conditioned medium.

Unstimulated mononuclear cells and 'monocytes' produced detectable BPA ( $2 \cdot 6$-fold and 2.1-fold stimulation of BFU-E respectively). PHA and Con A. but not PWM, increased the production of BPA by these cell populations. Neither unstimulated nor mitogen stimulated " $T$ cells' produced any detectable BPA when assayed with monocyte depleted (Fig 1) or T cell depleted (data not shown) target cells. T cells also produced no detectable BPA when stimulated with PHA concentrations up to $2.5 \mu \mathrm{l} / \mathrm{ml}$ or Con A concentrations up to 1.0 $\mu \mathrm{g} / \mathrm{ml}$ (data not shown). No media conditioned by mitogens alone (without cells) enhanced BFI-E growth.

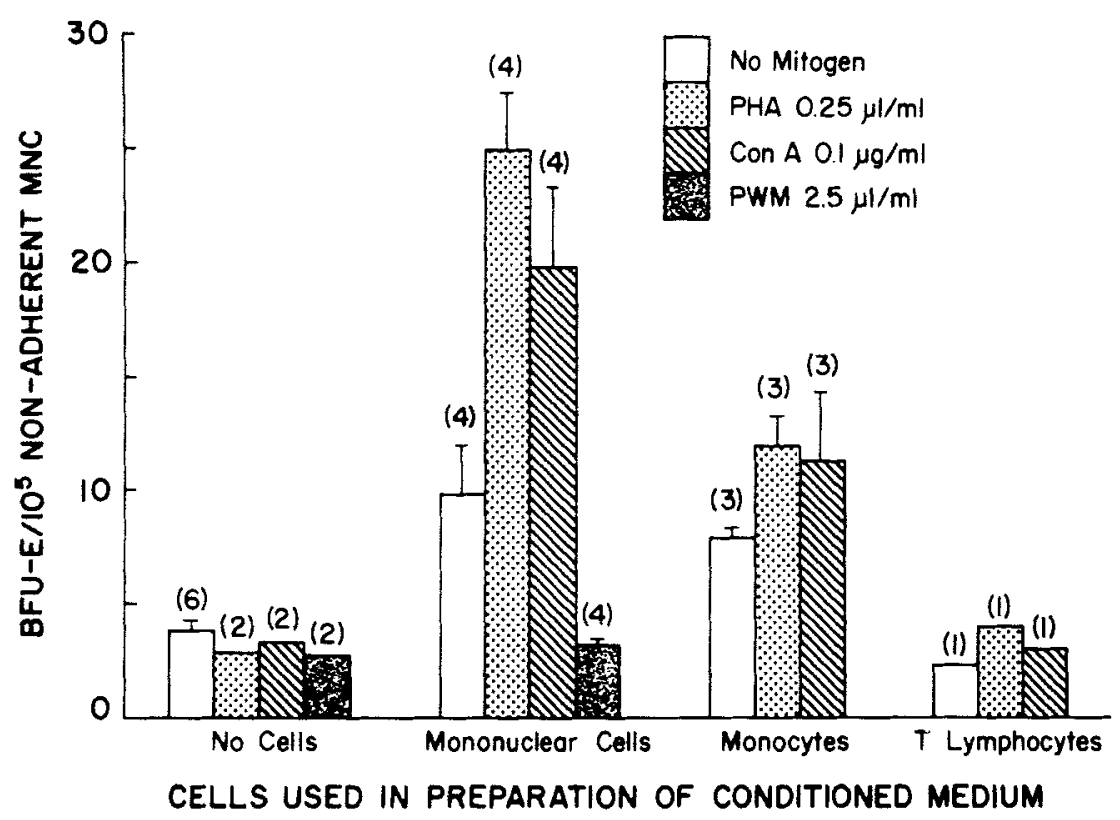

Fig 1. Production of erythroid burst promoting activity by unstimulated and mitogen stimulated human peripheral blood mononuclear cells. monocytes and $\mathrm{T}$ lymphocytes. Values are expressed as mean number of BFC-E ( \pm SEM) per $10^{5}$ non-adherent (monocyte-depleted) mononuclear cells (MNC) in cultures containing $10 \%$ conditioned medium from suspensions of the indicated cells incubated in the presence of the designated mitogen. Numbers in parentheses are the number of separate experiments (with three to six replicate cultures per experiment) used to calculate each datum point. 
Effect of varying concentrations of mitogens on BPA production by mononuclear cells

The dose-response curves for mitogen induced alteration of mononuclear cell BPA production in representative experiments are shown in Figs 2-4. PHA augmented BPA production by mononuclear cells from a 3.5-fold stimulation of BFU-E by conditioned medium from mononuclear cells alone to 8-9-fold stimulation of BFU-E when the mononuclear cells were incubated with $0 \cdot 5-1 \mu \mathrm{l}$ of PHA per ml (Fig 2). Similar findings were noted in three additional experiments, although a plateau level of augmentation was reached in two experiments with a PHA concentration of $0 \cdot 25 \mu \mathrm{l} / \mathrm{ml}$. Con A significantly augmented BPA production by mononuclear cells with Con A concentrations of 0.05 and $0 \cdot 1 \mu \mathrm{g} / \mathrm{mL}$ (6-fold stimulation of BFU-E) (Fig 3). Higher Con A concentrations up to $5 \mu \mathrm{g} / \mathrm{ml}$ resulted in no augmentation of BPA production. Similar results were obtained in two other experiments, but in one case BPA stimulation occurred with Con A concentrations up to $0.5 \mu \mathrm{g} / \mathrm{ml}$. All concentrations of PWM tested suppressed BPA production by mononuclear cells, with a plateau level of suppression at concentrations $\geqslant 1 \cdot 0 \mu \mathrm{l} / \mathrm{ml}$ (Fig 4). Similar results were obtained in two additional experiments.

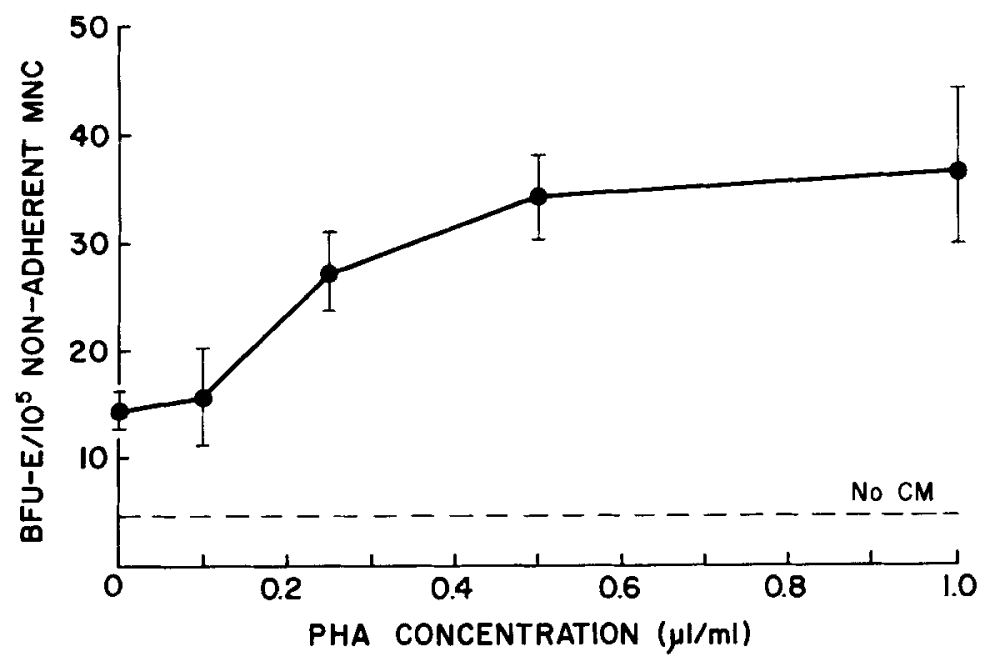

Fig 2. Effect of conditioned medium from PHA stimulated human peripheral blood mononuclear cells on human BFU-E growth in vitro. Values are expressed as mean number of BFU-E $( \pm \mathrm{SEM})$ per $10^{5}$ non-adherent (monocyte-depleted) mononuclear cells (MNC) in cultures containing $10 \%$ conditioned medium from MNC incubated in medium and serum alone or with the designated concentration of PHA. Each datum point represents the mean of three to six replicate cultures in a single representative experiment. The dashed line is a reference point representing the mean number of BFU-E per $10^{5}$ non-adherent MNC in cultures to which no conditioned medium was added.

\section{DISCUSSION}

Evidence is presented which confirms prior reports that normal human peripheral blood mononuclear cells (Zuckerman, 1980; Nathan et al, 1978; Aye, 1977; Eaves \& Eaves, 1978) 


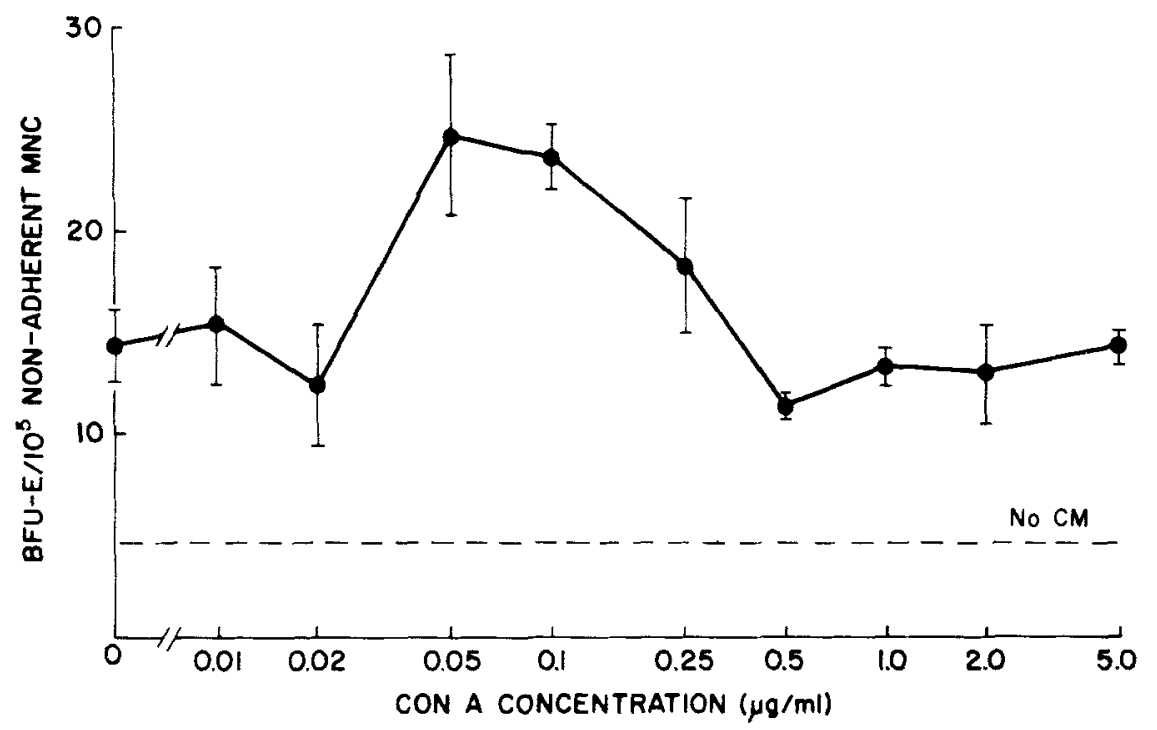

Fig 3. Effect of conditioned medium from Con A stimulated human peripheral blood mononuclear cells on human BFE-E growth in vitro. The values are expressed as described in the legend for Fig 2.

and monocytes (Zuckerman. 1980, 1981; Reid et al, 1981), but not $\mathrm{T}$ lymphocytes (Zuckerman, 1981; Nomdedeu et al, 1980: Torok-Storb et al, 1980; Lipton et al, 1980), are necessary for BPA production. The latter finding is in disagreement with the findings of Nathan et al (1978) and Mangan et al $(1980,1982)$, who reported production of BPA by T cells.

Although tetanus toxoid. PHA, and mixed leucocyte culture stimulated mononuclear cells all have been reported to produce BPA (Nathan et al, 1978: Aye, 1977; Eaves \& Eaves, 1978: Mangan \& Desforges. 1980: Meytes et al. 1979l, no effort has been made previously to

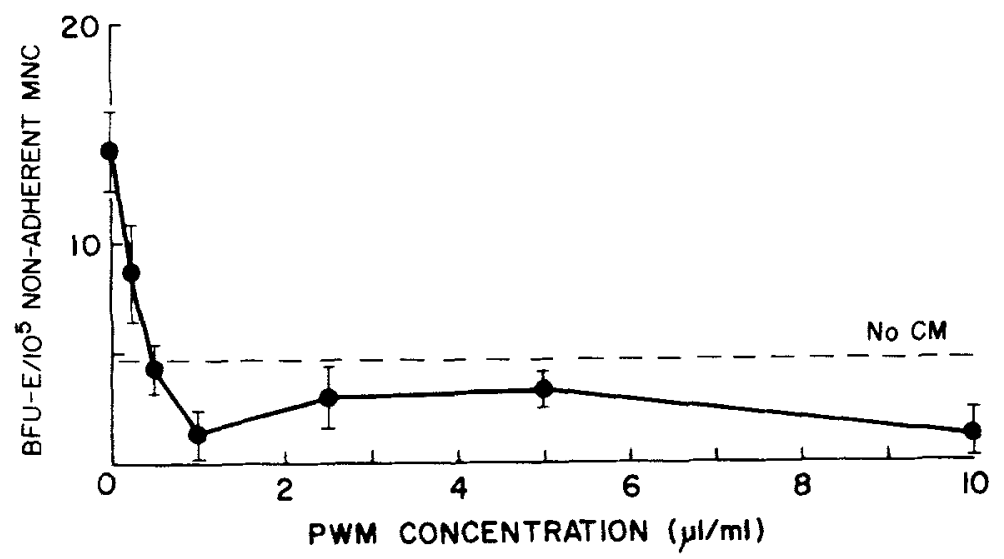

Fig 4. Effect of conditioned medium from PWM stimulated human peripheral blood mononuclear cells on human BFU-E growth in vitro. The values are expressed as described in the legend for Fig 2. 
study in depth factors that control BPA production in vitro. In the present study we have shown not only that unstimulated mononuclear cells and monocytes produce BPA, but also that their capacity to produce BPA can be altered substantially by such mitogens as PHA, Con $A$ and PWM.

The PHA and Con A induced enhancement of BPA production by mononuclear cells could be a result of one or more of the following: (1) direct stimulation of monocytes to produce BPA; (2) stimulation of Iymphocytes to produce a factor that enhances monocyte production of BPA; or (less likely) (3) direct stimulation of T lymphocytes to produce BPA, or (4) stimulation of monocytes to produce a factor that enhances lymphocyte production of BPA. In the presence of PHA or Con A, 'monocytes' produce 40-50\% more BPA than do unstimulated 'monocytes'. Although PHA and Con A certainly stimulate lymphocytes, it is well known that these mitogens also can bind to monocytes and macrophages and can stimulate them metabolically (Rosenstreich \& Oppenheim, 1976; Smith \& Goldman, 1971; Romeo et al, 1973; Vassilli et al, 1977). Since our T lymphocyte populations were highly purified, the lack of BPA production by unstimulated and mitogen stimulated $T$ cells does not prove that these cells are incapable of BPA production. It is conceivable that stimulated T cells may produce measurable quantities of BPA only when monocytes are present, as is the case with mitogen induced lymphocyte blastogenesis and ${ }^{3} \mathrm{H}$-thymidine incorporation (Rosenstreich \& Oppenheim, 1976).

Although PHA and Con A stimulated BPA production by human peripheral blood mononuclear cells, we were surprised to find that PWM, in a concentration-dependent manner, suppressed BPA production by mononuclear cells. The mechanism of this phenomenon is not known. The report of Hofman et al (1980) is of potential relevance to this observation. They found that PWM (but not Con A) induced monocytes to produce a soluble factor that suppressed cytotoxicity by stimulated mononuclear cells against various target cells. Perhaps a similar inhibitor of BPA production, release or activity is responsible for our results.

The previous studies cited above and the present findings are strong supportive evidence for the hypothesis that monocytes/macrophages produce substantially more BPA than do normal $\mathrm{T}$ lymphocytes. Results of prior studies from this laboratory indicate, however, that $\mathrm{T}$ cells may play an important role in enhancing BPA production by monocytes (Zuckerman, 1981). Other investigators have also reported an apparent synergistic effect of monocytes and T cells in production of BPA (Metcalf \& Johnson, 1978; Reid et al, 1981). This synergism between monocytes and lymphocytes in the production of BPA is demonstrated again by the marked enhancement of BPA production by unfractionated mononuclear cells stimulated by PHA and Con A in comparison to the more modest augmentation of BPA production by purified monocytes stimulated by these lectins.

\section{ACKNOWLEDGMENTS}

Supported in part by grant AM27340 from the National Institutes of Health, Junior Faculty Research Award JFRA-1 8 from the American Cancer Society, and a grant from the Children's Leukemia Foundation of Michigan, Inc. 


\section{REFERENCES}

ABbotd. C.N., Dipersio, J.F.. BrenwiN, J.K. \& LICHTMAx, M.A. ( 1980 ) Erythropoietic enhancing activity (EFA) secreted by the human cell line. GCT. Journal of Supramolecular Structure. 13. 199-209.

Ascensao, J.. KAY, N.F., EARforight-Exgl.F. T., KOREN. H.S. \& ZANJANI. E.D. 1981 , Production of erythroid potentiating factor(s) by a human monocytic cell line. Blood. 57, 170-173.

AYk. M.T. (197,) Erythroid colony formation in cultures of human marrow and in patients with polvcythemia vera. Joumal of Celhular Physiology. 91. 69-78.

Boyt. A. A 19681 Isolation of mononuclear cells and granulocytes from human blood. Scandinavian Journal of Laboratory and Clinical Imestigation. 21. Suppl. 97. 77-109.

Dukes. P.P., Meytes, D. MA. A., DiRocco. G.. ORTEGA. J.A. \& Shorf. N.A. 11978$)$ A urinary factor which stimulates erythroid burst formation more effectively than erythropoietin. Hematopoietic Cell Differentiation led. by D. II. Golde. M. J. Cline, D. Metcalf and C. F. Foxl. pp. 119-128. Academic Press, New York.

EAYYS. C.J. \& EAvEs. A.C. (1978) Erythropoietin dose-response curves for three classes of erythroid progenitors in normal human bone marrow and in patients with polycythemia vera. Blood, 52, 1196-1210.

Golde. D.W., Bersch. V.. Qtax. S.G. \& Lisis. A.J. (1980) Production of erythroid-potentiating activity by a human T-lymphoblast cell line. Procedings of the Vational Academy of Sciences of the United States of America. 77, 593-596.

Gordon, L.I, Milier. W.J.. Branda. R.F.. ZA.NIANI, E.D. \& J ACOB, H.S. 119801 Regulation of erythroid colony formation by bone marrow macrophages. Blood. 55. 1047-1050.

HAMBURGER. A. (1980) Enhancement of human erythroid progenitor cell growth by media conditioned by a human T-lymphocyte line. Blood. 56.633-639.

HARA. H. \& OGAWA. M. (197T) Erythropoietic precursors in mice under erythropoietic stimulation and suppression. Experimental Hematology. 5. $1+1-1+8$.

Hormax, F., SPINA, C.A., RAND, N. \& FAHEY, J.L. (1980) Soluble suppressor factor produced by pokeweed mitogen-stimulated human peripheral blood leukocytes. Cellular Immunology. 55 , $20-31$.

Iscove. N.N. (1977) The role of erythropoietin in regulation of population size and cell cycling of early and late erythroid precursors in mouse bone marrow. Cell and Tissue Kinetics, 10 , $323-334$.

Iscove. N.N. (1978) Erythropoietin-independent stimulation of early erythropoiesis in adult marrow cultures by conditioned media from lectin-stimulated mouse spleen cells. Hematopoietic Cell Differentiation (ed. by D. W. Golde. M. J. Cline. D. Metcalf and C. F. Fox), pp. 37-52. Academic Press. New York.

I.evitT, L., Fabian. I. \& Greenberg, P. (1982) Effect of pan-T-lymphocyte and anti-la-like (HLA-DR) monoclonal antibodies on human marrow pluripotential (CFU-GEMM) and committed (CFU-GM and BFU-E) hematopoietic progenitor cells. Experimental Hematology, 10 , Suppl. 11. 130.

Liptox. J.M., Reinherz, E.I.. Kudisch, M., JACKSon. P.L., Schlossman, S.F. \& Nathan, D.G. (1980) Mature bone marrow erythroid burstforming units do not require $T$ cells for induction of erythropoietin-dependent differentiation. Joumal of Experimental Medicine, 152, $350-360$.

Maxgan, K.F., Chikkappa. G., Biehler, I.Z., Scharfman, W.B. \& Parkinson, D.R. (1982) Regulation of human blood erythroid burstforming unit (BFU-E) proliferation by T-lymphocyte subpopulations defined by $F_{c}$ receptors and monoclonal antibodies. Blood, 59 , 990-996.

MANGAN, K.F. \& Desforges, J.F. (1980) The role of T lymphocytes and monocytes in the regulation of human erythropoietic peripheral blood burst-forming units. Experimental Hematology. 8. $717-727$.

Mendes, N.F., Tolnai, M.E.A., Silveira, N.P., GllbertSeN. S.B. \& MetizgAr, R.S. (1973) Technical aspects of the rosette tests used to detect human complement receptor (B) and sheep erythrocyte binding (T) lymphocytes. Journal of Immunology. 111, 860-867.

Metcalf. D. \& Johnson, G.R. (1978) Production 
by spleen and lymph node cells of conditioned medium with erythroid and other hemopoietic colony stimulating activity. Journal of Cellular Physiology, 196, 31-42.

Meytes, D., Ma, A., Ortega, J.A., Shore, N.A. \& DukEs, P.P. (1979) Human erythroid burstpromoting activity produced by phytohemagglutinin-stimulated radio-resistant peripheral blood mononuclear cells. Blood, 54, 10501057.

Nathan, D.G., Chess, L., Hillman, D.G., Clarke, B., Breard, J., Merler, E. \& Housman, D.E. (1978) Human erythroid burst-forming unit: T-cell requirement for proliferation in vitro. Journal of Experimental Medicine, 147, 324339.

Nissen, C., Iscove, N. \& SPEcK, B. (1979) High burst-promoting activity in serum of patients with acquired aplastic anemia. Experimental Hematology Today (ed. by S. J. Baum and G. D. Ledney), pp. 79-87. Springer, New York.

Nomdedeu, B., Gormus, B.J., Banisadre, M., RineHART, J.J., KAPLAN, M.E. \& ZANJANI, E.D. (1980) Human peripheral blood erythroid burst forming unit (BFU-E): evidence against a T lymphocyte requirement for proliferation in vitro. Experimental Hematology, 8, 845-852.

Porter, P.N. \& Ogawa, M. (1982) Characterization of human erythroid burst-promoting activity derived from bone marrow conditioned medium. Blood, 59, 1207-1212.

REID, C.D.L., Baptista, L.C.\& Chanarin, I. (1981) Erythroid colony growth in vitro from human peripheral blood null cells: evidence for regulation by $\mathrm{T}$ lymphocytes and monocytes. British Journal of Haematology, 48, 155-164.

Romeo, D., Zabucci, G. \& Rossi, F. (1973) Reversible metabolic stimulation of polymorphonuclear leukocytes and macrophages by concanavalin A. Nature, 243, 111-113.

Rosenstreich, D.L. \& OPPENHEIM, J.J. (1976) The role of macrophages in the activation of $\mathrm{T}$ and $\mathrm{B}$ lymphocytes in vitro. Immunobiology of the Macrophage (ed. by D. S. Nelson), pp. 161-199. Academic Press, New York.

Shaw, G.M., Levy, P.C. \& LoBuglio, A.F. (1978) Human monocyte antibody-dependent cellmediated cytotoxicity to tumor cells. Journal of Clinical Investigation, 62, 1172-1180.

SMITH, C.W. \& Goldman, A.S. (1971) Macrophages from human colostrum. Multinucleated giant cell formation by phytohemagglutinin and concanavalin A. Experimental Cell Research, 66, 317-320.

Tepperman, A.D., Curtis, J.E. \& McCulloch, E.A. (1974) Erythropoietic colonies in cultures of human marrow. Blood, 55, 659-669.

Torok-Storb, B.J., Seiff, C., Storb, R., Adamson, J.W. \& Thomas, E.D. (1980) In vitro tests for distinguishing possible immune-mediated aplastic anemia from transfusion-induced sensitization. Blood, 55, 211-215.

Tsang, R.W. \& AYE, M.T. (1979) Evidence for proliferation of erythroid progenitors in the absence of added erythropoietin. Experimental Hematology, 7, 383-388.

TuCKER, S.B., PierRe, R.V. \& Jordan, R.E. (1977) Rapid identification of monocytes in a mixed mononuclear cell preparation. Journal of Immunological Methods, 14, 267-269.

Vassalli, J.D., Hamilton, J. \& RFich, E. (1977) Macrophage plasminogen activator: Induction by concanavalin $A$ and phorbol myristate acetate. Cell, 11, 695-705.

ZuCKERMAN, K.S. (1980) Stimulation of human BFU-E by products of human monocytes and lymphocytes. Experimental Hematology. 8, 924-932.

ZUCKERMAN, K.S. (1981) Human erythroid burst forming units: Growth in vitro is dependent on monocytes, but not T lymphocytes. Journal of Clinical Investigation, 67, 702-709. 